\title{
骨粗鬆性椎体骨折に対する春椎後方除圧短縮固定術
}

\author{
木 村 皇太郎* 加 藤 圭 彦* 寒 竹 司* \\ 今 城 靖 明* 鈴木秀 典* 田口敏 彦*
}

\section{Posterior Spinal Shortening for Osteoporotic Vertebral Fracture}

\author{
Kotaro Kimura*, Yoshihiko Katoh*, Tsukasa Kanchiku*, Yasuaki Imajo*, \\ Hidenori Suzuki*, and Toshihiko Taguchi*
}

骨粗鬆性脊椎椎体骨折では遅発性神経障害や偽関節による疼痛の遷延化などの後遺障害が問題となるが， それらに対し奉椎後方除圧短縮固定術を施行し良好な成績を得たので報告する。症例は 24 例（男性 6 女 性 18)，手術時年齢は平均 75 歳，経過観察期間は 24 ヶ月。罹患骨折椎体は Th12 が 11 例，L1 が 8 例之 胸腰椎移行部に多かった。結果は臨床所見では旧 JOA スコア（胸椎 11 点満点）で術前 5.6 点が術後 7.8 点, 腰背部痛はVAS で術前 59.7 から術後 33 と改善. 遅発性神経障害合併 18 例の Frankel 分類は, 術 前 C 16 例 D 2 例が術後 C 9 例 D 9 例となり，新たな麻痺の発生はなかった。画像所見では局所後弯角か 術前 16.8 であったのが，術直後が 5.5 , そして最終調査時が 8.5 であり矯正損失 3 度と矯正角度は維持さ れ, また全例骨癒合した。 以上から短縮術は後弯の矯正と維持, 骨癒合, 臨床症状などを改善した。

Introduction: To assess the efficacy of posterior spinal shortening for paraparetic or pseudarthrosis patients following vertebral collapse owing to osteoporosis.

Materials and Methods: Twenty-four patients treated with posterior spinal shortening were examined retrospectively. All complications were recorded and analyzed in relation to radiological and clinical outcomes. The group consisted of six men and 18 women aged 57 to 87 years, with a mean age of 75 years. The follow-up period ranged from three to 44 months (average 24 months).

Result: Time of surgery ranged from 185 to 460 minutes, with an average of 307 minutes. Perioperative bleeding ranged from 174 to $3400 \mathrm{~g}$, with an average of $1100 \mathrm{~g}$. The angle of kyphosis was $16.5^{\circ}$; before surgery, $5.2^{\circ}$ after, and $8.5^{\circ}$ in the last follow-up. $8.2^{\circ}$ in the final period. The amount of correction was $11.3^{\circ}$, and correction loss was $3.0^{\circ}$. The mean thoracic JOA score improved from 5.6 points preoperatively to 7.8 points postoperatively.

Discussion: Vertebral compression fractures in osteoporosis are thought to be caused by comparatively minor forces, and are characterized by the late development and slow progression of paraplegia. Posterior spinal shortening can be a choice for treating both delayed paraparesis and pseudarthrosis following vertebral collapse owing to osteoporosis.

Key words : osteoporosis (骨粗鬆症), vertebral fractures (脊椎椎体骨折), spinal shortening（短縮術）

は じめに

軽微な外傷を機に発症する骨粗鬆性脊椎椎体骨折に よる後遺障害として, 遅発性神経障害や保存的治療に 抵抗する疼痛などが挙げられる. 今回当科で脊椎後方 除圧短縮固定術（以下，短縮術）を施行し比較的良好 な成績を得たので報告する。

\section{対象および方法}

対象は骨粗鬆症性脊椎骨折を来した症例のうち，遅 発性神経障害や保存的治療に抵抗した疼痛が残存し当 科にて手術を施行した 24 症例で, 男性 6 例, 女性 18 例. 手術時年齢は 57 歳から 87 歳 (平均 75 歳), 経過 観察期間は 3 ヶ月から 3 年 8 ヶ月 (平均 24 ヶ月)であっ た。遅発性神経障害を来した症例が 18 例，保存的治

\footnotetext{
* 山口大学大学院医学系研究科整形外科 Department of Orthopedic Surgery Yamaguchi University Graduate School of Medicine, Yamaguchi, Japan
} 
療に抵抗した症例が 6 例。罹患骨折椎体は Th10 2 例, Th11 2 例, Th12 11 例, L1 8 例, L3 1 例で 胸腰椎移行部が多かった。 術式は全例後方アプローチ の短縮術, 固定椎体は基本的に罹患椎体の上下 2 椎体 に椎弓根スクリューを挿入し固定した。また術中超音 波にて春髄の除圧を確認した。後療法は全身状態や疼 痛などを考慮しながら症例により適宜行ったが，基本 的には術後 2 日間はベッド上臥床安静，3 日目からコ ルセット装着下で離床許可とした。

\section{結果}

手術侵襲は，手術時間が平均 5 時間 7 分（3 時間 5 分から 7 時間 40 分), 出血量が平均 $1000 \mathrm{~g}$ (174 から 3400 g), な打輸血は多くの症例で $\mathrm{Hb} 8$ 以下を基準之 し適宜行い, 輸血に伴う有害事象は発生しなかった。 臨床評価としては旧 JOA スコア（胸椎 11 点満点） が, 平均で術前 5.6 点から術後 7.8 点と改善. また腰 背部の疼痛は全ての症例で改善がみられ, VAS で平 均術前 $58.7 \mathrm{~mm}$ から術後 $32.3 \mathrm{~mm}$ であった。 術前に 遅発性神経障害を来していた 18 例の Frankel 分類は, 術前 C16D 2 が，術後 C 9 D 9 に改善，また術前より 麻痺が悪化した症例はなかった。

画像所見としては, 単純 X-rayによる脊椎後弯角 の变化は, 平均で術前の 16.5 度が術後は 5.2 度と 11.3 度の後弯矯正を得た。さらに最終観察時では 8.2 度之矯正損失は 3 度であった。

また最終観察時の単純 X-ray にて, 全ての症例で 骨癒合を得られていることを確認した。

経過観察中の合併症として, 再手術となった症例は 合計 3 例であった。内訳はインストゥルメント脱転が 1 例, 深部感染症が 1 例, 術後硬膜外血腫による急性 下肢麻痺が 1 例であった. インストゥルメント脱転の 1 例は 73 歳女性, Th12 破裂骨折に対する手術後, 術後 3 週目の Xray で椎弓根スクリューの脱転を確認, 初回手術から 4 週後に再手術となり歩行器歩行可能な 状態で他院転院された。他に深部感染症と術後硬膜外 血腫を発症した症例については，各々再手術にて感染 病巣搔爬や血腫除去術を行い, インプラントの抜去を 行うことなく経過し両者とも歩行器歩行可能な歩容レ ベルになった段階で他院へ転院された。

\section{症 例 呈 示}

86 歳女性. Th12 圧迫骨折後遅発性神経障害. 症状
は腰痛と両下肢の脱力感で歩容は車椅子．現病歴は特 に誘因なく腰痛出現。近医にて単純 X-ray 撮像され Th12 圧迫骨折と診断, 軟性コルセット装着し通院に よる保存的治療を行っていたが，1 ケ月後頃から両下 肢の脱力感が出現し, 徐々に増悪. 別の病院にて椎体 後壁の破壊に伴う遅発性神経障害と診断（図 1 )。症 状の改善が期待できないことから，受傷から５ヶ月で 当院にて手術を行うこととなった．臨床所見は MMT が術前 EHL，FHL が両側 F， その他下肢筋力は $\mathrm{G}$ であったものが術後 1 ヶ月経過時で左 IP, QC, Ham が $\mathrm{G}$, その他は $\mathrm{N}$ に改善, 歩容も車椅子から歩行器 歩行可能となった. Frankel 分類は術前 C が術後 D に改善. 胸椎 JOA スコアも 7 点から 9 点に改善した. インストゥルメントトラブルなど来すことなく経過良 好, 転院された（図２）。

\section{考察}

現在まで，上述した症例に対する手術的治療には様々 な方法が行われている ${ }^{1)}$. アプローチの違いや，椎体 形成術など術式の違いなど様々であり，未だ統一した 見解が得られていないようである，短縮術は罹患椎体 後壁を含む脊柱後方要素を切除短縮することで，十分 な後弯矯正が得られる。また後弯の軽減によりインス トゥルメントの脱転を予防しょうとするねらいがあ

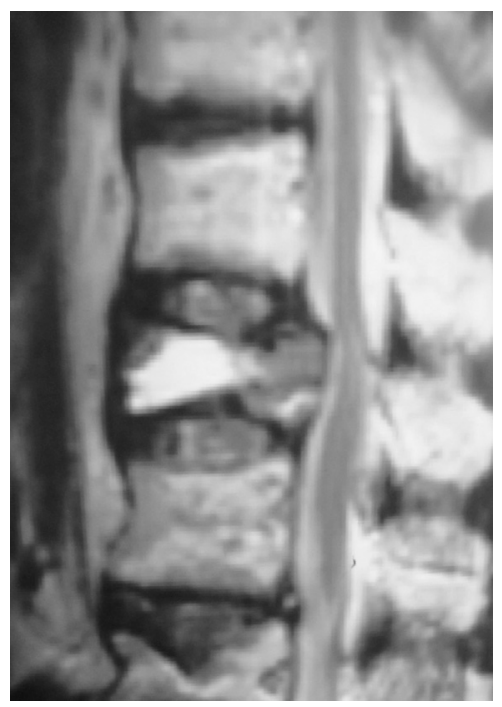

図 1 MRI：Th12 椎体後壁破壊による脊䯣圧 迫, 䯣内輝度変化 


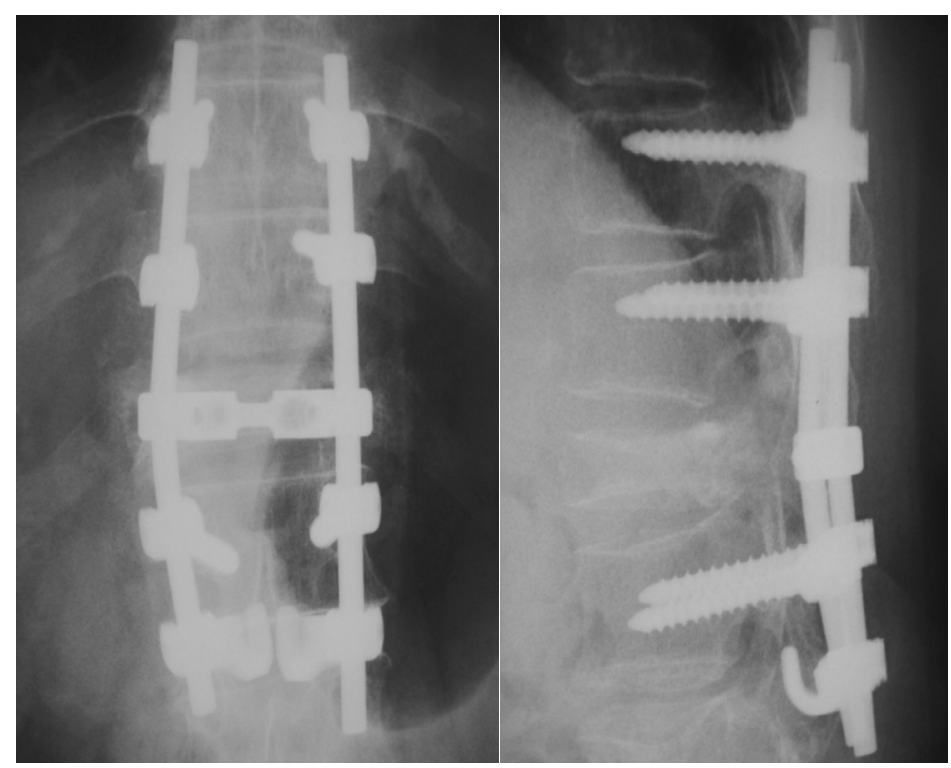

図 2 短縮術：術後単純 X-ray（正面，側面）

る 2)3). さらに当科では後弯矯正の維持を目的として, 後弯の無理な矯正を行わないことや，椎弓根スクリュー 挿入穴に HA を補填すること，また十分に骨移植を 行うことなどあ適宜行っている. その結果, 後弯矯正 11.3 度, 矯正損失 3 度と十分な後弯矯正と維持を得 られた。手術時間や出血量などの手術侵襲が大きいこ とや，インストゥルメントトラブルや感染のリスク， 固定端椎体の新規骨折発症などの問題点むあるものの, 十分な後弯矯正と維持, そして良好な臨床成績を得ら れており, 骨粗鬆性椎体骨折後遺障害に対して短縮術
は有効な術式と考えた。

\section{参 考 文 献}

1) Hasegawa, K., et al. : Vertebral pseudarthrosis in osteoporotic spine. Spine, 23 : 2201-2206, 1998.

2) Saita, K., et al. : Posterior spinal shortening for paraplegia after vertebral collapse caused by osteoporosis. Spine, 25 : 2832-2835, 2000.

3) Saita, K., et al. : Posterior spinal shortening for paraparesis following vertebral collapse due to osteoporosis. Spinal Cord, $46: 16-20,2008$. 